\title{
A Quantitative Look at the Relationship between FDI Inflow and Economic Growth in North Macedonia, 2006-2018
}

\author{
Bettina Jones \\ PhDc. University American College Skopje \\ Program Analyst, Appalachian Regional Commission \\ 1666 Connecticut Ave, Suite 700, Washington, D.C. 20009, USA \\ Tel: 1-859-397-0036 E-mail: bettinajones22@gmail.com
}

Received: August 20, 2020 Accepted: September 14, 2020 Published: September 16, 2020

doi:10.5296/ber.v10i4.17548

URL: https://doi.org/10.5296/ber.v10i4.17548

\begin{abstract}
Beginning in 2006, the North Macedonian government pursued a strategy for attracting foreign investment to the country to develop it economically. In theory, FDI inflow should have this effect in a developing country mainly by contributing to productivity spillovers to domestic firms and knowledge spillovers to the domestic labor force. The goal of the research was to determine what statistical association might exist between FDI inflow and economic growth in North Macedonia, to determine if the policy of FDI attraction was having one of its desired effects. The paper fleshes out the economic growth function $\mathrm{Y}=\mathrm{F}(\mathrm{K}, \mathrm{H}, \mathrm{L}, \mathrm{A})$; growth is a function of capital, human capital, labor, and technology to determine which variables to utilize. It was found that neither FDI inflow nor any of the other considered factors for economic growth had a significant association with growth. However, taken together, all these factors did a moderately good job of explaining the variation in economic growth over the considered period. Thus, arguments for FDI inflow's being a silver bullet for economic growth may be misplaced, as many other factors matter as well. This does not suggest that foreign direct investment ought not to be used as an economic development tool, however, as it may be having effects that are not captured by changes in economic growth.
\end{abstract}

Keywords: Foreign direct investment, Economic growth, Development economics, Economic development, International business

\section{Introduction}

One of the most common reasons why foreign direct investment (FDI) is pursued by 
developing countries is that it is often associated with good economic outcomes, including general economic growth. The logic is that the FDI unlocks the potential of domestic firms and generates opportunities for the creation of products and services that the domestic market may not demand, and helps domestic firms orient more towards global markets, both in mindset and in network development. The injection of foreign capital into a developing economy can positively impact the local construction sector, local employment, and the domestic supply chain, as well as contributing to the country's account balance. Economic growth is generally accepted as an indicator of economic well-being, with GDP per capita forming one-third of the trifecta of the human development index. GDP growth is therefore considered in this work as indicative of general economic/human development. North Macedonia began an intense policy of FDI attraction in 2006, with related subsidies and other supports, for the goal of contributing to the country's overall economic growth and, thus, providing a better life for its citizens. The work seeks to determine whether over the life of the policy (2006 to the present day) gains in economic growth can be attributed to FDI inflow on its own, or if perhaps some other factor is responsible. This is especially important for countries like North Macedonia, who carry out large and expensive programs in order to attract FDI to their countries. Determining the true effects of FDI on the growth of a developing economy will enable policymakers generally to perform cost-benefit analyses of programs related to FDI, and update their policies accordingly. The effects of policies in general should always be evidence-based, and particularly when it comes to activities like FDI, which involves the public sector's financial involvement in the market.

The paper hypothesizes that the effects of FDI inflow on economic growth over the period considered in North Macedonia will not be as pronounced as has been argued by state officials. The paper firstly reviews the relevant scholarship on the relationship between foreign direct investment and economic growth. The second section provides the methodological approach to the statistical analysis, including the theoretical bases for the different variables that explain economic growth. The third section provides some regional context of FDI inflow in North Macedonia and examines the data graphically and numerically. The fourth section provides the result of the regression between economic growth and FDI inflow, among other variables. The fifth section discusses the results of the analysis, and the sixth section concludes.

\section{Literature Review}

Most countries prefer FDI over other types of investment due to its "stable nature, low volatility, and long-term commitment" (Sawalha, Elian, and Suliman, 2016). Proponents would argue that FDI inflows bring good to an economy for several reasons. They can be thought of as a debt-free investment in the economy of a country, can increase the quantity and quality of employment, and can result in technological and managerial spillovers to domestic firms (Bruno and Campos, 2011). These positive spillovers can be measured by examining the decreases in the gaps in total factor productivity between the domestic firms and the MNCs over time (Manral, 2001). Furthermore, FDI aids in local enterprise development, helps create a competitive business environment, and contributes to the country's ability to integrate into international trade networks (Bari, n.d.). All of these factors 
then contribute to economic growth.

The role of foreign businesses is also very significant for key export industries developing countries. In Vietnam, for instance, foreign businesses contributed to $75 \%$ of total exports of footwear; 35\% of garments and textiles and 95\% of electronics (Menon, 2009). However, it may be that the productivity benefits of FDI only take hold when the workforce of the FDI host country is sufficiently educated (Borenzstein, De Gregorio, and Lee, 1998) or if the economy and financial markets are sufficiently developed (deMello, 1999; Alfaro et. al, 2003). Borenzstein et. al (1998) found that the interaction between FDI and human capital is significant for growth in developing countries, but FDI alone is not. The mixed productivity effects of FDI was also found by Kathuria, who showed that increased sales for domestic firms following an investment by a foreign firm only occurred only if the domestic firm invested strongly in R\&D, but for those that didn't, sales decreased (Manral, 2001).

Similarly, it was found that FDI has a significant positive impact on welfare in countries where the governance is of higher quality (i.e. only the interaction term between governance and FDI was positively significant for a regression examining a country's performance on the Human Development Index (HDI). It was further found that FDI alone had a surprising negative impact on knowledge infrastructure, or the technological framework within the country including IP right protections, absorptive abilities, and the like. This may be due to foreign companies protecting their intellectual property through various means or because of the country's technology transfer policies (Lehnert et. al, 2013).

The literature therefore identifies many qualifiers of the direct relationship between FDI inflow and economic growth. It seems that FDI inflow alone is not enough to cause it, but FDI can contribute when other factors including quality governance, well-developed human capital, advanced domestic firms, and others. Moreover, in the economic growth/FDI relationship there also is the potential problem of direction of causality, which can be controlled for through the use of the Granger (1969) or Sims (1972) tests (Oladipo, 2012). This directionality problem explains in part why authors researching on the topic of the relationship between economic growth and FDI incidence report contradictory results. Specifically, the problem is that it is very possible that growth in a particular sector is followed by investment in that sector in that country, rather than the investment causing the growth. Investors certainly do include growth in various industries and/or countries as one of the key items under consideration when they make investment decisions (Alfaro, 2003).

The methodology of the paper attempts to control for all these various factors that can contribute to economic growth in the country so as to determine whether there is an isolated effect of FDI, or whether there is an effect of FDI that will only take hold in the presence of another variable.

\section{Methodology}

In order to determine the relationship of FDI to the variable of economic growth, a regression is performed in this section that examines the span of time from the beginning of the policy until the most recent data is available (2018), which will also enable the determination of 
some preliminary macroeconomic results of the change in policy.

Economic growth as measured by the GDP growth rate since the previous year is the dependent variable with FDI inflow as a percentage of GDP as the independent variable of interest. To increase the total number of observations, the quarterly GDP growth rate was used, along with the annual statistics for each of the other indicators, added four times for each year. It was done in this way because the other variables were not available on a quarterly basis, but the $\mathrm{n}$ is still increased through the use of the quarterly GDP data. The other variables were selected due to their association with economic growth according to a combination of economic growth theories/models. The other independent variables included in the regression were the real interest rate, foreign exchange reserves as a percentage of money supply, gross fixed capital formation as a percentage of GDP, broad money supply as a percentage of GDP, gross domestic savings as a percentage of GDP, the population growth rate, expenditure on $R \& D$ as a percentage of GDP, the political stability index, average years of expected schooling, incoming official development assistance (ODA; i.e. foreign aid) as a percentage of GDP, and incoming remittances as a percentage of GDP. The latter two capture the other two major types of foreign inflows of money that can impact economic outcomes in addition to foreign direct investment (Lehnert et. al, 2013). Foreign exchange reserves similarly controls for foreign capital in the country and how it may contribute to internal growth. The paper has used the growth function $\mathrm{Y}=\mathrm{F}(\mathrm{K}, \mathrm{L}, \mathrm{H}, \mathrm{A})$; economic growth is a function of capital, labor, human capital, and technology. It based the variables selected to represent this function on a combination of different economic growth models, including the Solow-Swan, Harrod-Domar, and endogenous growth models. Accumulation of capital, both human and financial, forms the contribution of the Solow-Swan model (Renelt, 1991). Gross fixed capital formation, broad money supply, and average years of expected schooling are its associated variables. The Harrod-Domar model contributes gross domestic savings as a percentage of GDP, which drives growth through capital accumulation (System Dynamics, 2016). The model also contributes the population growth rate, which affects the productivity of labor. Endogenous growth theory holds that internal/human capital development contributes to economic growth (Renelt, 1991), and provides research development, measured by R\&D investment as a percentage of GDP, and average years of expected schooling. Also included was the interest rate, which directly affects growth by encouraging or discouraging investment. Finally, the political stability index is also included to control for the extent to which economic growth in the country might have been affected by conflict. It is a particularly important variable for the context of North Macedonia, which has seen a recent war of independence, civil war, ethnic conflict, and a political crisis.

There were 52 observations total, with no missing data points. There were some limitations of the data: Though economic growth is recorded on a quarterly basis, none of the other variables are. This led to repetition of all of the variables four times a year to match the changing growth variable. The results would have been much more robust if quarterly data had been available for all of them. Only 12 observations are available for the other variables, which is a low number of observations. Similarly, the quarterly economic growth figure is volatile, so attempting to use quarterly data to increase the number of observations may affect 


\section{Macrothink}

the validity of the results.

\section{Data Analysis}

Firstly, the analysis will examine the descriptive statistics for the FDI inflow-economic growth regression:

Descriptive Statistics

\begin{tabular}{|l|l|l|l|l|l|}
\hline Variable & Obs & Mean & Std.Dev. & Min & Max \\
\hline Year & 52 & 2012.135 & 4.05 & 2000.2 & 2018.4 \\
\hline GDPGrowth & 52 & .539 & 2.563 & -3.7 & 10.4 \\
\hline FDIInflowGDP & 52 & 4.208 & 2.022 & .5 & 8.8 \\
\hline InterestRate & 52 & 5.746 & 2.472 & 1.7 & 10.8 \\
\hline ForExMS & 52 & .557 & .077 & .44 & .7 \\
\hline FixedCapGDP & 52 & 23.231 & 1.359 & 20.1 & 25.8 \\
\hline BroadMSofGDP & 52 & 45.303 & 7.885 & 29.3 & 55.47 \\
\hline SchoolYears & 52 & 12.985 & .411 & 12.2 & 13.5 \\
\hline ODAofGDP & 52 & 1.918 & .427 & 1.33 & 2.9 \\
\hline RemittOfGDP & 52 & 3.562 & .579 & 2.7 & 4.1 \\
\hline PolStability & 52 & -.358 & .234 & -.74 & .26 \\
\hline DomSavGDP & 52 & 10.331 & 5.853 & 2.8 & 20.4 \\
\hline PopGrowth & 52 & .085 & .022 & .05 & .14 \\
\hline RandDofGDP & 52 & .319 & .117 & .17 & .52 \\
\hline
\end{tabular}

Where the variables are, in order: GDP growth, FDI net inflow as a percentage of GDP, real interest rate, foreign exchange reserves as a percentage of money supply, gross fixed capital formation as a percentage of GDP, broad money supply as a percentage of GDP, average years of expected schooling, ODA (i.e. foreign aid) inflow as a percentage of GDP, remittances as a percentage of GDP, the political stability index, the gross domestic savings rate as a percentage of GDP, the population growth rate, and R\&D expenditure as a percentage of GDP. The full dataset is in appendix.

Looking at the raw data, it is clear that GDP growth is generally lower today than it was at the beginning of the period of interest: 


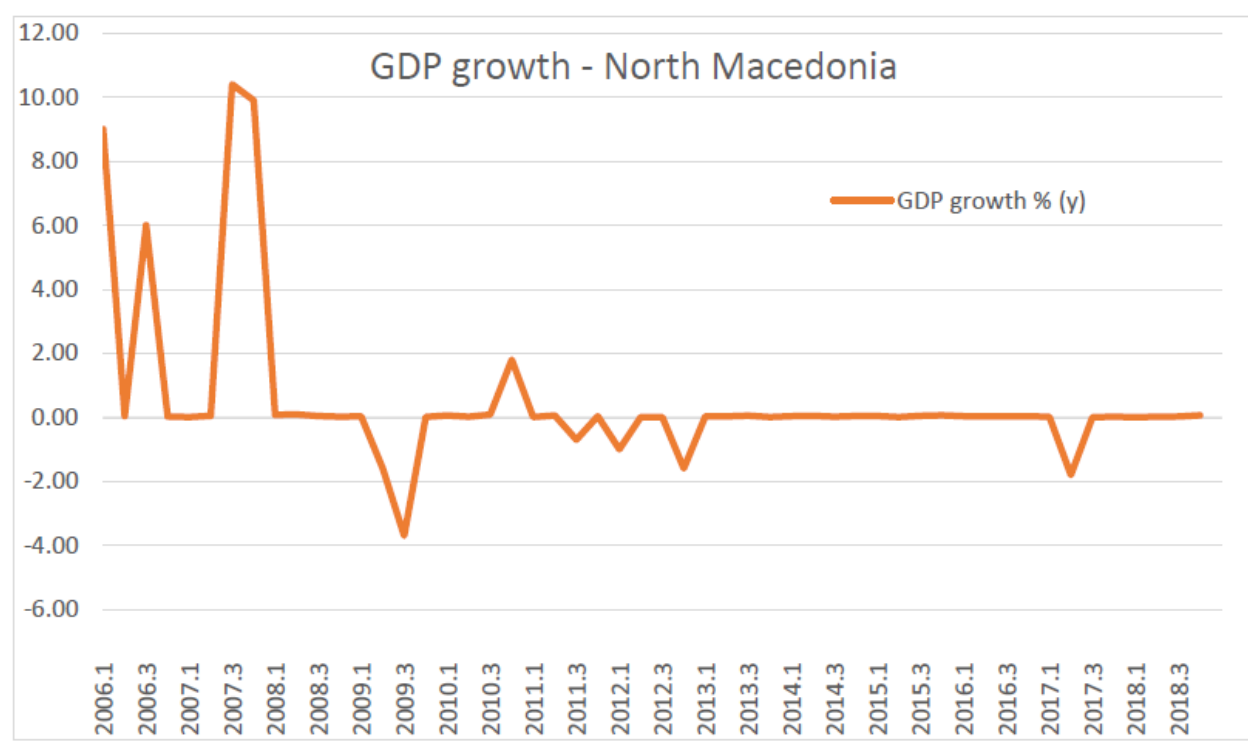

Figure 1. Quarterly GDP Growth in North Macedonia

The low points correspond largely to political or economic crises. The low growth in 2009 is likely due to the consequences of the 2008 global financial crisis. The 2011/2012 dip can be explained by the European Sovereign Debt Crisis, wherein North Macedonia's neighbor Greece was hard hit. The 2017 low growth is likely due to the 2015-2017 political crisis in the country. Next, FDI inflow over time will be examined:

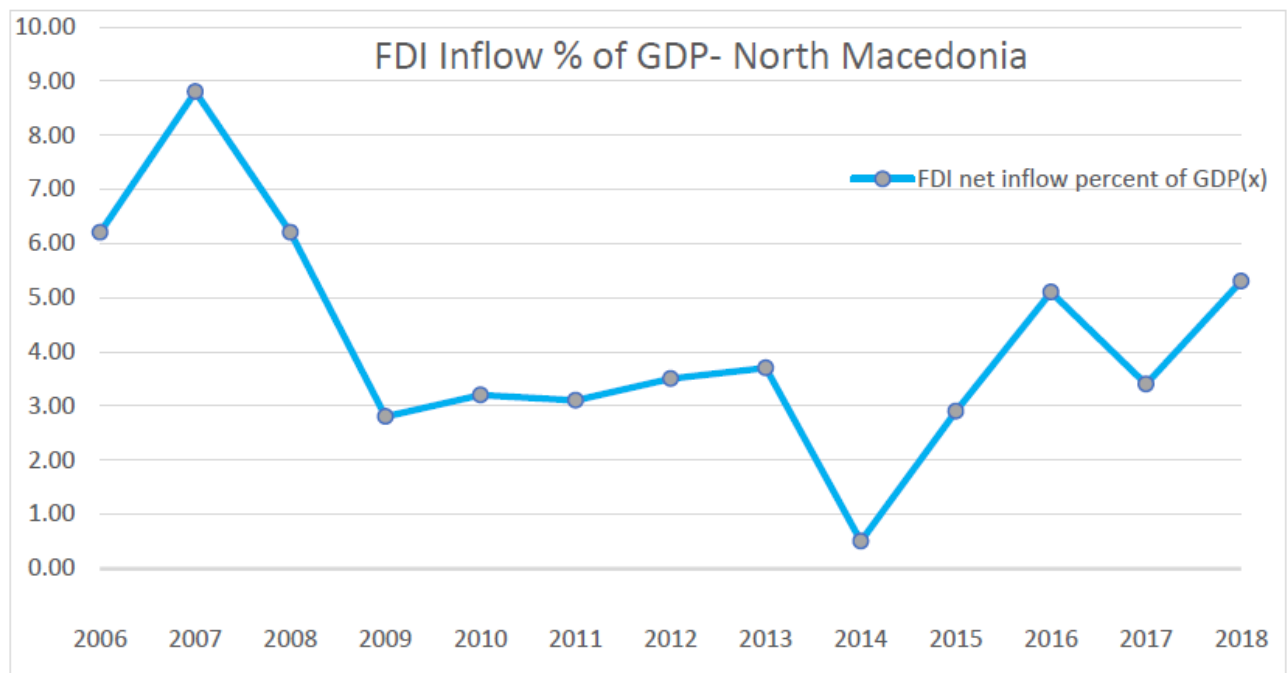

Figure 2. FDI Inflow over time as a percentage of GDP in North Macedonia

It is clear here that FDI also began at a higher percentage of GDP and decreased over time, rebounding after 2015. This strong start is largely due to the increased level of privatization of formerly state-owned industries in former Yugoslavia throughout the 1990s and early 2000s. To put these trends into perspective, numbers for the GDP growth rate and FDI inflow 
were examined just before the 2006 policy period. GDP growth had been steadily increasing, in a rebound that occurred after falling into negative growth during and following the 2001 civil war, and then appears to have reached a peak of growth in 2007 , when greenfield investments began occurring, and fell to fluctuating between 3 or $4 \%$ and $0 \%$. Prior to the start of the policy period, FDI had seen a drastic increase in FDI inflow in 2001, interestingly, during the civil war. This outlier was caused by the acquisition of the country's national telecommunications operator by the Deutsche Telekom Group in that year. FDI then dropped to hover between 2 and 5\% before the policy period. Interestingly, the graphs show a strong performance with regard to both GDP and FDI at the beginning of the policy period, a drop at the time of the financial crisis, and then a rebound, but not a full recovery.

First, the analysis will look at the relationship between FDI inflow and economic growth without any of the additional variables. The scatterplot between the variables is below.

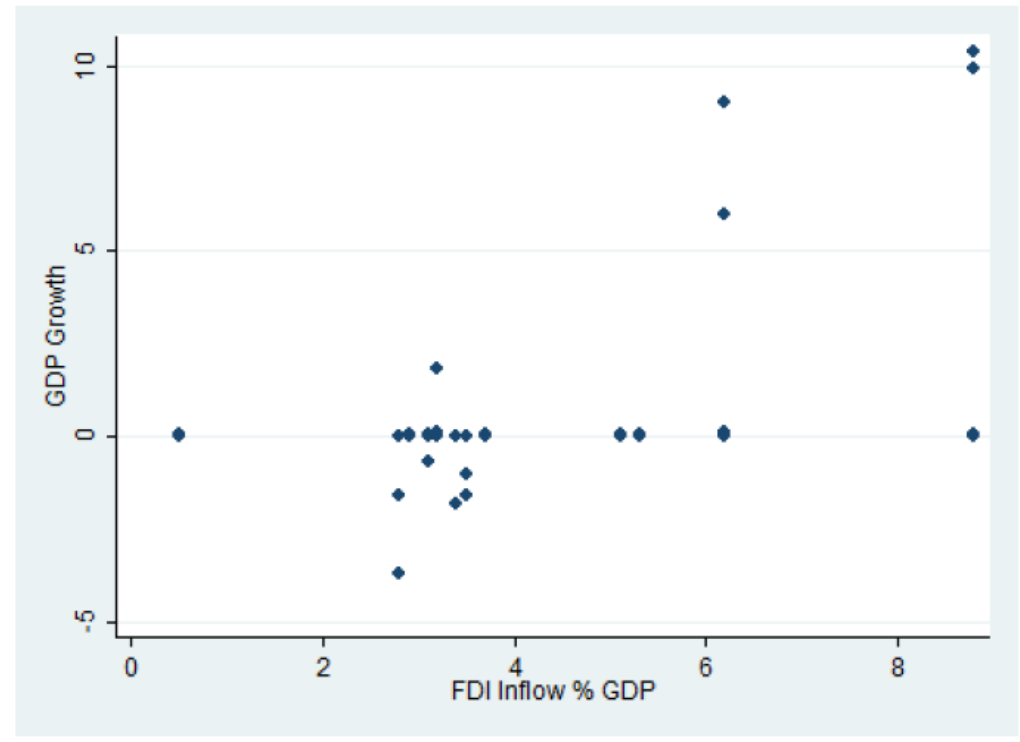

Figure 3. Scatterplot of FDI Inflow with GDP Growth

There is a clear visual association between the two variables when seen this way. However, a regression with the two variables alone will provide a clearer picture of their associative relationship.

Linear regression

\begin{tabular}{|c|c|c|c|c|c|c|c|c|}
\hline GDPGrowth & Coef. & St.Err. & t-value & p-value & \multicolumn{2}{|c|}{$[95 \%$ Conf } & Interval] & Sig \\
\hline FDIInflowGDP & 0.637 & 0.155 & 4.11 & 0.000 & \multicolumn{2}{|l|}{0.326} & 0.948 & $* * *$ \\
\hline Constant & -2.14 & 0.722 & -2.96 & 0.005 & \multicolumn{2}{|l|}{-3.591} & -0.690 & $* * *$ \\
\hline \multicolumn{2}{|c|}{ Mean dependent var } & 0.539 & \multicolumn{3}{|c|}{ SD dependent var } & \multicolumn{3}{|c|}{2.563} \\
\hline \multicolumn{2}{|l|}{ R-squared } & 0.252 & \multicolumn{3}{|c|}{ Number of obs } & \multicolumn{3}{|c|}{52.000} \\
\hline \multicolumn{2}{|l|}{ F-test } & 16.886 & \multicolumn{3}{|c|}{ Prob $>F$} & \multicolumn{3}{|c|}{0.000} \\
\hline \multicolumn{2}{|l|}{ Akaike crit. (AIC) } & 233.295 & \multicolumn{3}{|c|}{ Bayesian crit. (BIC) } & 237. & & \\
\hline
\end{tabular}


$* * * \mathrm{p}<0.01, * * \mathrm{p}<0.05, * \mathrm{p}<0.1$

It appears, according to this regression between only GDP growth and FDI inflow, that there is a moderate, significant, positive relationship, where the p-value is much smaller than .05 , and the R-Squared is 25 . This would indicate that FDI inflow alone is responsible for $25 \%$ of the variation in economic growth over the period, which, were it a final result, would provide ample evidence that FDI inflow is in fact associated with economic growth. However, adding many more variables complicates the picture and provides that it is likely other factors that truly account for the variation.

\section{Results}

The following regression considers all the variables, including those in the economic growth model created in the work, political stability, interest rate, and other foreign inflow of capital variables:

Linear regression

\begin{tabular}{|c|c|c|c|c|c|c|c|c|}
\hline GDPGrowth & Coef. & St.Err. & t-value & p-value & \multicolumn{2}{|c|}{$[95 \%$ Conf } & Interval] & Sig \\
\hline FDIInflowGDP & 1.557 & 3.451 & 0.45 & 0.654 & \multicolumn{2}{|c|}{-5.423} & 8.537 & \\
\hline InterestRate & 0.694 & 1.331 & 0.52 & 0.605 & \multicolumn{2}{|l|}{-1.999} & 3.387 & \\
\hline ForExMS & -21.308 & 50.177 & -0.42 & 0.673 & \multicolumn{2}{|c|}{-122.801} & 80.184 & \\
\hline FixedCapGDP & 0.255 & 1.887 & 0.14 & 0.893 & \multicolumn{2}{|c|}{-3.563} & 4.072 & \\
\hline BroadMSofGDP & -0.277 & 0.699 & -0.40 & 0.694 & \multicolumn{2}{|c|}{-1.691} & 1.137 & \\
\hline SchoolYears & 5.600 & 47.478 & 0.12 & 0.907 & \multicolumn{2}{|c|}{-90.434} & 101.634 & \\
\hline ODAofGDP & 4.826 & 20.252 & 0.24 & 0.813 & \multicolumn{2}{|c|}{-36.137} & 45.788 & \\
\hline RemittOfGDP & 19.338 & 55.848 & 0.35 & 0.731 & \multicolumn{2}{|c|}{-93.626} & 132.302 & \\
\hline PolStability & 4.660 & 8.746 & 0.53 & 0.597 & \multicolumn{2}{|c|}{-13.030} & 22.350 & \\
\hline DomSavGDP & 2.056 & 4.667 & 0.44 & 0.662 & \multicolumn{2}{|c|}{-7.385} & 11.497 & \\
\hline PopGrowth & 113.772 & 278.536 & 0.41 & 0.685 & \multicolumn{2}{|c|}{-449.620} & 677.164 & \\
\hline RandDofGDP & 19.463 & 84.861 & 0.23 & 0.820 & \multicolumn{2}{|c|}{-152.185} & 191.112 & \\
\hline Constant & -177.768 & 917.006 & -0.19 & 0.847 & \multicolumn{2}{|c|}{-2032.588} & 1677.051 & \\
\hline \multicolumn{3}{|l|}{ Mean dependent var } & \multicolumn{3}{|c|}{ SD dependent var } & \multicolumn{2}{|c|}{2.563} & \\
\hline R-squared & \multicolumn{2}{|c|}{0.465} & \multicolumn{3}{|c|}{ Number of obs } & \multicolumn{2}{|c|}{52.000} & \\
\hline F-test & \multicolumn{2}{|c|}{2.823} & \multicolumn{3}{|c|}{ Prob $>F$} & $0.00^{\circ}$ & & \\
\hline Akaike crit. (AIC) & 237 & 911 & & esian crit & (BIC) & 263.2 & & \\
\hline
\end{tabular}

$* * * \mathrm{p}<0.01, * * \mathrm{p}<0.05, * \mathrm{p}<0.1$

In the regression that considers all variables, none of the variables are found to be significant. Though insignificant, they all have a positive relationship with economic growth, save foreign exchange reserves as a percentage of money supply and broad money supply as a percentage of GDP. However, the adjusted r-squared is 47, and the F-statistic's p-value is 
significant. This indicates that the variables considered here are relatively good determinants of Macedonia's economic growth over this period, as they together can explain $47 \%$ of its variation and shows significance.

\section{Discussion}

Interestingly, the complete regression considering all variables, including the interest rate and political stability index, result in just a moderately high adjusted r-squared. All of these factors represent what in the literature is written to be causes of economic growth. The theories seem to apply moderately well in our case, to explain Macedonia's economic growth from 2006 to 2018. Significantly, neither FDI inflow nor any other variable is significant in the full regression, where many aspects are considered including variables meant to control for capital accumulation, technological development, and increases in socioeconomic status. Again, it is possible that the wild fluctuations in the quarterly data has caused this. It may also be the volatility inherent in the numbers themselves.

North Macedonia has in the past 12 years experienced vast changes. In 2005 it became a candidate for EU membership, a process which has since stalled (though since 2017, the trajectory has been somewhat reestablished). The country has seen internal ethnic clashes, 11 years of what has been described as state capture, the effects of the 2008 financial crisis, the 2015 refugee crisis, the effects of the European Sovereign Debt Crisis, rapprochement with Greece, and most recently, successful accession to NATO. The starting point for growth was also quite low, with the country only gaining independence in 1991, just 15 years prior to the start of the policy. It also endured wars between its neighbors throughout the 1990s and experienced a civil war of its own in 2001. It may be that economic growth has been wildly fluctuating due to these events or otherwise unaccounted for factors. Though political stability is also accounted for in the regression, it could be that changes in the index occur at different times than changes in the business market. It is possible that market changes lag behind political events, or that socioeconomic indicators lag behind market indicators. For now it is clear that there remain unknown factors in economic growth in Macedonia over the policy period, and FDI inflow seems not to have made much difference. This finding agrees with the paper's overall hypothesis that the notion that FDI inflow is one of the major factors for North Macedonia's economic growth over the past 15 or so years is overstated by officials. However, as none of the other factors were significant either, it is likely that economic growth is a complicated phenomenon that requires many different elements to be in place to happen.

\section{Conclusion}

The finding that over the policy period FDI inflow is not associated with economic growth does not suggest that FDI should not be utilized as an economic development tool. It seems that, especially when utilized alongside other mechanisms, it can contribute to economic growth. What the results point out is merely that FDI inflow is not a silver bullet for economic growth, but must be accompanied by programs and reforms in other areas to truly contribute. This notion would agree with the paper's hypothesis. It also demonstrates that there are yet-to-be-determined factors that contribute to economic growth, and that would be a good area for future research. It is highly recommended that North Macedonian 
policymakers examine these results and incorporate them into any future cost-benefit consideration for crafting FDI-related programming. They should keep in mind that FDI inflow seems not to singlehandedly cause economic growth. Other developing countries would do well to perform such statistical analyses as this one and use the results to inform their FDI policy decisions accordingly.

\section{References}

Alfaro, L., Chanda, A., Kalemli-Ozcan, S., \& Sayek, S. (2003). FDI and Economic Growth: The Role of Local Financial Markets. Journal of International Economics.

https://doi.org/10.2139/ssrn.305762

Bari, M. (n.d.). Foreign Direct Investment and Economic Growth in Bangladesh and India: A Comparative Study. South Asian Journal of Management, 20(1). 7-37.

Borensztein, E., De Gregorio, J., \& Lee, J. W. (1998). How Does Foreign Direct Investment Affect Economic Growth?. Journal of International Economics, 45, 115-135.

https://doi.org/10.1016/S0022-1996(97)00033-0

Bruno, R., \& Campos, N. (2011). Foreign Direct Investment and Economic Performance: A Systematic Review of the Evidence Uncovers a New Paradox. Department for International Development Systematic Reviews Programme.

DeMello, L. (1997). Foreign Direct Investment in Developing Countries and Growth: A Selective Survey. The Journal of Development Studies, 34(1), 1-34.

https://doi.org/10.1080/00220389708422501

Lehnert, K., Benmamoun, M., \& Zhao, K. (2013). FDI Inflow and Human Development: Analysis of FDI's Impact on Host Countries' Social Welfare and Infrastructure. Wiley Periodicals Inc Feature Article. Thunderbird International Business Review, 55(3), 285-298. https://doi.org/10.1002/tie.21544

Manral, L. (2001). Technology Transfer and the Spillover Effect to Local Firms: Evidence from India. Academy of Management Executive, 15(2), 129-130.

https://doi.org/10.5465/ame.2001.4615023

Menon, J. (2009). Managing Success in Vietnam: Macroeconomic Consequences of Large Capital Inflows with Limited Instruments. ASEAN Economic Bulletin, 26(1), 77-95.

https://doi.org/10.1355/AE26-1F

Oladipo, O. (2012). Does Foreign Direct Investment Cause Long Run Economic Growth? Evidence from the Latin American and the Caribbean Countries. International Economic Policy, 10, 569-582. https://doi.org/10.1007/s10368-012-0225-4

Renelt, D. (1991). Economic Growth: A Review of the Empirical Literature. Policy, Research, and External Affairs Working Papers; Macroeconomic Adjustment and Growth. Country Economics Department. The World Bank. [Online] Available: https://bit.ly/3c4BybD

Sawalha, N., Elian, M., \& Suliman, A. (2016). Foreign Capital Inflows and Economic 
Growth in Developed and Emerging Economies: A Comparative Analysis. The Journal of Developing Areas, 50(1). https://doi.org/10.1353/jda.2016.0022

System Dynamics Conference Papers (2016). Exploring Harrod Domar and Solow Models of Economic Growth. [Online] Available: https://bit.ly/30XsIbD

\section{Appendix}

Appendix A: Full dataset

\begin{tabular}{|c|c|c|c|c|c|c|c|c|c|c|c|c|c|}
\hline Year & $\begin{array}{l}\text { GDP } \\
\text { growth \% } \\
\text { (y) }\end{array}$ & $\begin{array}{l}\text { FDI net } \\
\text { inflow } \\
\text { percent } \\
\text { of GDP(x) }\end{array}$ & $\begin{array}{l}\text { Real } \\
\text { Interest } \\
\text { rate }\end{array}$ & $\begin{array}{l}\text { Foreign } \\
\text { Exchange } \\
\text { Reserves } \\
\% \text { of } \\
\text { money } \\
\text { supply }\end{array}$ & $\begin{array}{l}\text { Gross } \\
\text { Fixed } \\
\text { Capital } \\
\text { Formatio } \\
\mathrm{n}(\% \text { of } \\
\text { GDP) }\end{array}$ & $\begin{array}{l}\text { Broad } \\
\text { Money } \\
\text { Supply, \% } \\
\text { of GDP }\end{array}$ & $\begin{array}{l}\text { Average } \\
\text { years of } \\
\text { expected } \\
\text { schooling }\end{array}$ & $\begin{array}{l}\text { ODA as a } \\
\% \text { of GDP }\end{array}$ & $\begin{array}{l}\text { Remittan } \\
\text { ces } \\
\text { received, } \\
\% \text { of GDP }\end{array}$ & $\begin{array}{l}\text { Stability } \\
\text { index }\end{array}$ & $\begin{array}{l}\text { Gross } \\
\text { Domestic } \\
\text { Savings \% } \\
\text { of GDP }\end{array}$ & $\begin{array}{l}\text { Populatio } \\
\text { n growth } \\
\text { rate }\end{array}$ & $\begin{array}{l}\text { R\&D as } \% \\
\text { of GDP }\end{array}$ \\
\hline 2006 & 9.00 & 6.20 & 8.00 & 0.64 & 20.10 & 29.30 & 12.20 & 2.90 & 3.90 & -0.74 & 4.40 & 0.14 & 0.19 \\
\hline 2000.2 & 0.04 & 6.20 & 8.00 & 0.64 & 20.10 & 29.30 & 12.20 & 2.90 & 3.90 & -0.74 & 4.40 & 0.14 & 0.19 \\
\hline 2006.3 & 6.00 & 6.20 & 8.00 & 0.64 & 20.10 & 29.30 & 12.20 & 2.90 & 3.90 & -0.74 & 4.40 & 0.14 & 0.19 \\
\hline 2006.4 & 0.02 & 6.20 & 8.00 & 0.64 & 20.10 & 29.30 & 12.20 & 2.90 & 3.90 & -0.74 & 4.40 & 0.14 & 0.19 \\
\hline 2007 & 0.01 & 8.80 & 5.70 & 0.70 & 22.70 & 39.20 & 12.20 & 2.41 & 4.10 & -0.43 & 5.90 & 0.11 & 0.17 \\
\hline 2007.2 & 0.05 & 8.80 & 5.70 & 0.70 & 22.70 & 39.20 & 12.20 & 2.41 & 4.10 & -0.43 & 5.90 & 0.11 & 0.17 \\
\hline 2007.3 & 10.40 & 8.80 & 5.70 & 0.70 & 22.70 & 39.20 & 12.20 & 2.41 & 4.10 & -0.43 & 5.90 & 0.11 & 0.17 \\
\hline 2007.4 & 9.90 & 8.80 & 5.70 & 0.70 & 22.70 & 39.20 & 12.20 & 2.41 & 4.10 & -0.43 & 5.90 & 0.11 & 0.17 \\
\hline 2008 & 0.08 & 6.20 & 4.50 & 0.57 & 25.80 & 36.80 & 13.00 & 2.04 & 4.10 & -0.30 & 2.80 & 0.09 & 0.22 \\
\hline 2008.2 & 0.09 & 6.20 & 4.50 & 0.57 & 25.80 & 36.80 & 13.00 & 2.04 & 4.10 & -0.30 & 2.80 & 0.09 & 0.22 \\
\hline 2008.3 & 0.04 & 6.20 & 4.50 & 0.57 & 25.80 & 36.80 & 13.00 & 2.04 & 4.10 & -0.30 & 2.80 & 0.09 & 0.22 \\
\hline 2008.4 & 0.02 & 6.20 & 4.50 & 0.57 & 25.80 & 36.80 & 13.00 & 2.04 & 4.10 & -0.30 & 2.80 & 0.09 & 0.22 \\
\hline 2009 & 0.03 & 2.80 & 10.80 & 0.62 & 24.60 & 39.40 & 13.00 & 2.10 & 4.10 & -0.30 & 4.20 & 0.08 & 0.20 \\
\hline 2009.2 & -1.60 & 2.80 & 10.80 & 0.62 & 24.60 & 39.40 & 13.00 & 2.10 & 4.10 & -0.30 & 4.20 & 0.08 & 0.20 \\
\hline 2009.3 & -3.70 & 2.80 & 10.80 & 0.62 & 24.60 & 39.40 & 13.00 & 2.10 & 4.10 & -0.30 & 4.20 & 0.08 & 0.20 \\
\hline 2009.4 & 0.01 & 2.80 & 10.80 & 0.62 & 24.60 & 39.40 & 13.00 & 2.10 & 4.10 & -0.30 & 4.20 & 0.08 & 0.20 \\
\hline 2010 & 0.06 & 3.20 & 8.50 & 0.55 & 23.10 & 43.90 & 12.90 & 2.10 & 4.10 & -0.52 & 6.20 & 0.08 & 0.22 \\
\hline 2010.2 & 0.02 & 3.20 & 8.50 & 0.55 & 23.10 & 43.90 & 12.90 & 2.10 & 4.10 & -0.52 & 6.20 & 0.08 & 0.22 \\
\hline 2010.3 & 0.09 & 3.20 & 8.50 & 0.55 & 23.10 & 43.90 & 12.90 & 2.10 & 4.10 & -0.52 & 6.20 & 0.08 & 0.22 \\
\hline 2010.4 & 1.80 & 3.20 & 8.50 & 0.55 & 23.10 & 43.90 & 12.90 & 2.10 & 4.10 & -0.52 & 6.20 & 0.08 & 0.22 \\
\hline 2011 & 0.01 & 3.10 & 5.70 & 0.59 & 23.50 & 42.90 & 12.90 & 1.83 & 4.10 & -0.62 & 8.00 & 0.08 & 0.22 \\
\hline 2011.2 & 0.06 & 3.10 & 5.70 & 0.59 & 23.50 & 42.90 & 12.90 & 1.83 & 4.10 & -0.62 & 8.00 & 0.08 & 0.22 \\
\hline 2011.3 & -0.70 & 3.10 & 5.70 & 0.59 & 23.50 & 42.90 & 12.90 & 1.83 & 4.10 & -0.62 & 8.00 & 0.08 & 0.22 \\
\hline 2011.4 & 0.04 & 3.10 & 5.70 & 0.59 & 23.50 & 42.90 & 12.90 & 1.83 & 4.10 & -0.62 & 8.00 & 0.08 & 0.22 \\
\hline 2012 & -1.00 & 3.50 & 8.00 & 0.62 & 23.40 & 47.90 & 12.90 & 1.50 & 4.00 & -0.49 & 7.50 & 0.09 & 0.33 \\
\hline 2012.2 & 0.01 & 3.50 & 8.00 & 0.62 & 23.40 & 47.90 & 12.90 & 1.50 & 4.00 & -0.49 & 7.50 & 0.09 & 0.33 \\
\hline 2012.3 & 0.00 & 3.50 & 8.00 & 0.62 & 23.40 & 47.90 & 12.90 & 1.50 & 4.00 & -0.49 & 7.50 & 0.09 & 0.33 \\
\hline 2012.4 & -1.60 & 3.50 & 8.00 & 0.62 & 23.40 & 47.90 & 12.90 & 1.50 & 4.00 & -0.49 & 7.50 & 0.09 & 0.33 \\
\hline 2013 & 0.03 & 3.70 & 3.80 & 0.56 & 23.70 & 44.10 & 12.90 & 1.81 & 3.50 & -0.42 & 10.70 & 0.09 & 0.44 \\
\hline 2013.2 & 0.03 & 3.70 & 3.80 & 0.56 & 23.70 & 44.10 & 12.90 & 1.81 & 3.50 & -0.42 & 10.70 & 0.09 & 0.44 \\
\hline 2013.3 & 0.05 & 3.70 & 3.80 & 0.56 & 23.70 & 44.10 & 12.90 & 1.81 & 3.50 & -0.42 & 10.70 & 0.09 & 0.44 \\
\hline 2013.4 & 0.01 & 3.70 & 3.80 & 0.56 & 23.70 & 44.10 & 12.90 & 1.81 & 3.50 & -0.42 & 10.70 & 0.09 & 0.44 \\
\hline 2014 & 0.03 & 0.50 & 6.20 & 0.55 & 23.40 & 45.50 & 13.00 & 1.87 & 3.20 & 0.26 & 13.10 & 0.08 & 0.52 \\
\hline 2014.2 & 0.04 & 0.50 & 6.20 & 0.55 & 23.40 & 45.50 & 13.00 & 1.87 & 3.20 & 0.26 & 13.10 & 0.08 & 0.52 \\
\hline 2014.3 & 0.02 & 0.50 & 6.20 & 0.55 & 23.40 & 45.50 & 13.00 & 1.87 & 3.20 & 0.26 & 13.10 & 0.08 & 0.52 \\
\hline 2014.4 & 0.04 & 0.50 & 6.20 & 0.55 & 23.40 & 45.50 & 13.00 & 1.87 & 3.20 & 0.26 & 13.10 & 0.08 & 0.52 \\
\hline 2015 & 0.04 & 2.90 & 5.30 & 0.44 & 23.80 & 55.47 & 13.30 & 2.13 & 3.00 & -0.29 & 14.20 & 0.08 & 0.44 \\
\hline 2015.2 & 0.01 & 2.90 & 5.30 & 0.44 & 23.80 & 55.47 & 13.30 & 2.13 & 3.00 & -0.29 & 14.20 & 0.08 & 0.44 \\
\hline 2015.3 & 0.05 & 2.90 & 5.30 & 0.44 & 23.80 & 55.47 & 13.30 & 2.13 & 3.00 & -0.29 & 14.20 & 0.08 & 0.44 \\
\hline 2015.4 & 0.06 & 2.90 & 5.30 & 0.44 & 23.80 & 55.47 & 13.30 & 2.13 & 3.00 & -0.29 & 14.20 & 0.08 & 0.44 \\
\hline 2016 & 0.04 & 5.10 & 3.40 & 0.47 & 24.10 & 55.47 & 13.50 & 1.58 & 2.70 & -0.35 & 17.70 & 0.07 & 0.44 \\
\hline 2016.2 & 0.02 & 5.10 & 3.40 & 0.47 & 24.10 & 55.47 & 13.50 & 1.58 & 2.70 & -0.35 & 17.70 & 0.07 & 0.44 \\
\hline 2016.3 & 0.02 & 5.10 & 3.40 & 0.47 & 24.10 & 55.47 & 13.50 & 1.58 & 2.70 & -0.35 & 17.70 & 0.07 & 0.44 \\
\hline 2016.4 & 0.03 & 5.10 & 3.40 & 0.47 & 24.10 & 55.47 & 13.50 & 1.58 & 2.70 & -0.35 & 17.70 & 0.07 & 0.44 \\
\hline 2017 & 0.01 & 3.40 & 3.10 & 0.45 & 21.90 & 54.90 & 13.50 & 1.33 & 2.80 & -0.25 & 19.20 & 0.06 & 0.40 \\
\hline 2017.2 & -1.80 & 3.40 & 3.10 & 0.45 & 21.90 & 54.90 & 13.50 & 1.33 & 2.80 & -0.25 & 19.20 & 0.06 & 0.40 \\
\hline 2017.3 & 0.00 & 3.40 & 3.10 & 0.45 & 21.90 & 54.90 & 13.50 & 1.33 & 2.80 & -0.25 & 19.20 & 0.06 & 0.40 \\
\hline 2017.4 & 0.02 & 3.40 & 3.10 & 0.45 & 21.90 & 54.90 & 13.50 & 1.33 & 2.80 & -0.25 & 19.20 & 0.06 & 0.40 \\
\hline 2018 & 0.00 & 5.30 & 1.70 & 0.48 & 21.90 & 54.10 & 13.50 & 1.34 & 2.70 & -0.20 & 20.40 & 0.05 & 0.36 \\
\hline 2018.2 & 0.02 & 5.30 & 1.70 & 0.48 & 21.90 & 54.10 & 13.50 & 1.34 & 2.70 & -0.20 & 20.40 & 0.05 & 0.36 \\
\hline 2018.3 & 0.02 & 5.30 & 1.70 & 0.48 & 21.90 & 54.10 & 13.50 & 1.34 & 2.70 & -0.20 & 20.40 & 0.05 & 0.36 \\
\hline 2018.4 & 0.06 & 5.30 & 1.70 & 0.48 & 21.90 & 54.10 & 13.50 & 1.34 & 2.70 & -0.20 & 20.40 & 0.05 & 0.36 \\
\hline
\end{tabular}


B. Compressed dataset (annual figures only)

\begin{tabular}{|c|c|c|c|c|c|c|c|c|c|c|c|}
\hline Year & $\begin{array}{l}\text { GDP } \\
\text { growth } \\
\%(y)\end{array}$ & $\begin{array}{l}\text { FDI net } \\
\text { inflow } \\
\text { percent } \\
\text { of GDP(x) }\end{array}$ & $\begin{array}{l}\text { Real } \\
\text { Interest } \\
\text { rate }\end{array}$ & $\begin{array}{l}\text { Foreign } \\
\text { Exchange } \\
\text { Reserves in } \\
\text { billions }\end{array}$ & $\begin{array}{l}\text { Gross } \\
\text { Fixed } \\
\text { Capital } \\
\text { Formation } \\
\text { (\% of GDP) }\end{array}$ & $\begin{array}{l}\text { Broad } \\
\text { Money } \\
\text { Supply } \\
\text { (MKD billions) }\end{array}$ & $\begin{array}{l}\text { GNI per } \\
\text { capita, } \\
\text { PPP } \\
\text { (dollars) }\end{array}$ & $\begin{array}{l}\text { Average } \\
\text { years of } \\
\text { expected } \\
\text { schooling }\end{array}$ & $\begin{array}{l}\text { Foreign } \\
\text { exchange } \\
\text { rate (to USD) }\end{array}$ & $\begin{array}{l}\text { ODA in } \\
\text { millions }\end{array}$ & $\begin{array}{l}\text { Remittances } \\
\text { received, } \\
\% \text { of GDP }\end{array}$ \\
\hline 2006 & 5.1 & 6.2 & 8.0 & 1.3 & 20.1 & 109.54 & 8550 & 12.2 & 48.8 & 200.9 & 3.9 \\
\hline 2007 & 6.5 & 8.8 & 5.7 & 2.3 & 22.7 & 177.38 & 8810 & 12.2 & 44.7 & 201.8 & 4.1 \\
\hline 2008 & 5.5 & 6.2 & 4.5 & 2.1 & 25.8 & 198.35 & 10290 & 13 & 41.9 & 202.8 & 4.1 \\
\hline 2009 & -0.4 & 2.8 & 10.8 & 2.3 & 24.6 & 201.66 & 10840 & 13 & 44.1 & 194.2 & 4.1 \\
\hline 2010 & 3.4 & 3.2 & 8.5 & 2.3 & 23.1 & 225.09 & 11120 & 12.9 & 46.5 & 194.3 & 4.1 \\
\hline 2011 & 2.3 & 3.1 & 5.7 & 2.7 & 23.5 & 245.18 & 11400 & 12.9 & 44.2 & 192.3 & 4.1 \\
\hline 2012 & -0.5 & 3.5 & 8.0 & 2.9 & 23.4 & 252.69 & 11580 & 12.9 & 47.9 & 147.7 & 4 \\
\hline 2013 & 2.9 & 3.7 & 3.8 & 2.7 & 23.7 & 259.28 & 12350 & 12.9 & 46.4 & 196.7 & 3.5 \\
\hline 2014 & 3.6 & 0.5 & 6.2 & 2.9 & 23.4 & 282.41 & 13120 & 13 & 46.4 & 211.9 & 3.2 \\
\hline 2015 & 3.9 & 2.9 & 5.3 & 2.5 & 23.8 & 304.07 & 13400 & 13.3 & 55.5 & 214.3 & 3 \\
\hline 2016 & 2.8 & 5.1 & 3.4 & 2.8 & 24.1 & 322.2 & 14220 & 13.5 & 55.7 & 168.4 & 2.7 \\
\hline 2017 & 0.2 & 3.4 & 3.1 & 2.8 & 21.9 & 336.99 & 14690 & 13.5 & 54.7 & 149.9 & 2.8 \\
\hline 2018 & 2.7 & 5.3 & 1.7 & 3.3 & 21.9 & 373.44 & 15670 & 13.5 & 52.1 & 169.9 & 2.7 \\
\hline
\end{tabular}

\section{Copyright Disclaimer}

Copyright for this article is retained by the author(s), with first publication rights granted to the journal.

This is an open-access article distributed under the terms and conditions of the Creative Commons Attribution license (http://creativecommons.org/licenses/by/4.0/). 